\title{
John T. Houghton
}

\author{
An Oxford atmospheric physicist and experimenter on early NASA weather satellites who revolutionized the field \\ through leadership of the Appleton Laboratory, the Meteorological Office and the Science Board of the IPCC.
}

S ir John Houghton, an academic physicist who pioneered Earth observation from space in the 1960s and fought on the world stage to save the planet from harmful climate change, has died aged 88 on 15 April at his home in north Wales. He was diagnosed with the COVID-19 virus but had been ill with dementia for many years prior and suffered a serious fall last year.

John Theodore Houghton was born on 30 December 1931 in Dyserth, a small village on the north coast of Wales. He was rated the top student in the Principality based on his examination results at Rhyl Grammar School, an achievement that qualified him for the Meyricke Scholarship at Jesus College, Oxford, in 1948 when he was only 16 years old. Having duly achieved the top First in Physics at Oxford in 1951, inspired by lecturers such as Sydney Chapman and Gordon Dobson, John applied to read for a doctorate with Alan Brewer, head of a small group in the Clarendon Laboratory. John's project involved making and flying a primitive instrument mounted on a high-altitude aircraft to measure radiation fluxes in the atmosphere. After graduating, he did similar work at the Royal Aircraft Establishment, Farnborough, for four years, long enough to qualify as the military service then required of young men in the UK. Following this, he returned to Oxford to rejoin Brewer's group as a university lecturer.

When Brewer moved on to a position in Canada in 1962, John Houghton took over the Readership and the leadership of the Meteorology group, promptly renaming it Atmospheric Physics. When I joined as a post-graduate student in 1966, the group was engaged on flying radiometer apparatus on a high-altitude balloon, intending to convince NASA that a small British team had what it takes to deliver an instrument for one of their early weather satellites. Remarkably, this was successful, and I remember finding John in his tiny office scrolling through a telex more than ten feet long bringing the good news from the Agency, with a huge grin on his face. The device (developed with his former Farnborough colleague Desmond Smith, then at Reading University), the Selective Chopper Radiometer, flew on Nimbus 4 in April 1970.

Improved versions followed every few years, and by the time of the launch of Nimbus 7 in 1979, the principle of remote sensing of weather and climate from space

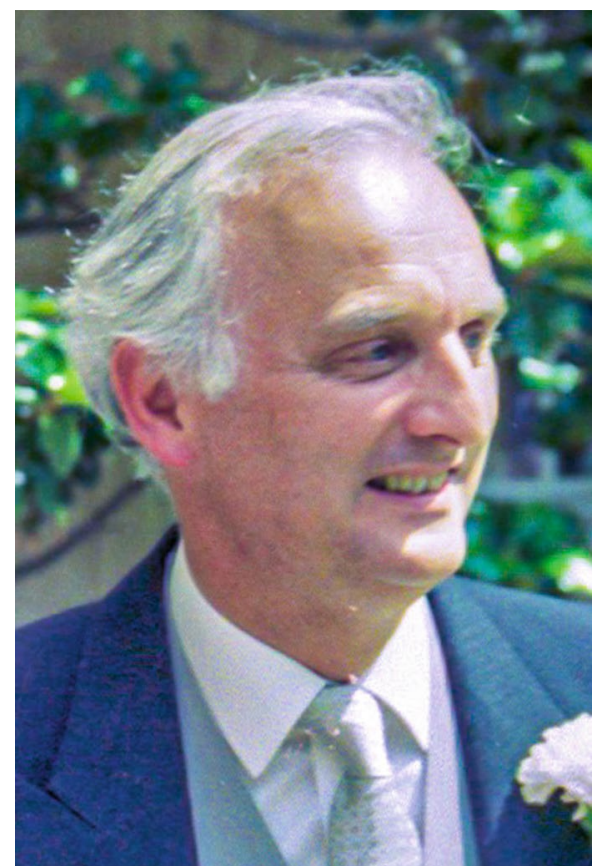

John T. Houghton (1931-2020). Credit: Doris Taylor.

using infrared radiation measurements was well established. John Houghton was now a scientist of international repute, with a personal chair at Oxford. He was restless, however. His ambitions (for his work; he never showed much interest in personal glory) and his prodigious energy levels led him to become Director of the Appleton Laboratory and to drive its integration with another big national facility, the Rutherford, to produce a world-class facility for research and engineering, including space instrumentation.

By 1983, Rutherford Appleton was successfully up and running at Harwell, and John would have returned to Oxford were it not for the retirement of Sir John Mason at the UK Meteorological Office. In the search for a successor, John Houghton was targeted. He said he would have to be mad to run such a large and variegated organization, but deep inside he needed fresh worlds to conquer, and pretty soon he took it on. A successful term as Director General usually earns a decoration; however, this was placed in jeopardy when in October 1987 a great storm, which the Met Office failed to forecast properly, struck the south of England and caused awful damage. There were calls for John's head, or at least his job, on the floor of Parliament, and he was privately distraught; he had never failed at anything before.

Fortunately the storm passed, literally and figuratively, and John survived to collect a knighthood and achieve his ambitions for the Met Office, including extending its remit from day-to-day weather forecasting to address climate change on much longer timescales. This would require a new team of many talents and a very large computer; in order not to disturb the Office's traditional role a separate organization, the Hadley Centre, was set up to grasp the climate nettle, and this continues to flourish today.

John was a religious man his whole life. His roots in the Welsh Presbyterian church stayed with him, and he was a lay preacher among other works, including several books that explored the boundaries between science and religion. His faith included the conviction that God had given us the stewardship of the Earth and expected us to look after it. This, and his deep knowledge of climate physics (also the subject of several important books), led him to play an important role in the World Climate Research Program, going on to the founding of the Intergovernmental Panel on Climate Change in 1988 and its first major Assessment Report in 1990. He hated the many meetings, with their slow progress, bureaucracy and in-fighting, but stuck to the task until his chairmanship of the science assessment team ended with the Third Assessment Report in 2001. Today, the IPCC is writing its Sixth Assessment Report and Working Group I has announced its report will be dedicated to John Houghton. I once asked him if the challenges posed by climate change were not so great as to cause him to despair sometimes; the reply was "absolutely not - it is a totally solvable problem." If it is solved, his contribution will surely be the greatest of his many achievements.

\section{Fred Taylor $₫$ \\ Clarendon Laboratory, University of Oxford, Oxford, UK. Fredric W. Taylor is Halley Professor Emeritus at Oxford University. He was John Houghton's successor as Head of the Atmospheric Physics Department at Oxford and a lifelong collaborator. $\bigotimes_{\text {e-mail:Fred.Taylor@physics.ox.ac.uk }}$}

Published online: 2 June 2020

https://doi.org/10.1038/s41558-020-0801-5 